\title{
Trade openness and wage inequality: evidence for Malaysia
}

\begin{abstract}
This article examines the impact of trade openness on wage inequality in Malaysia during the period 1984-1997. Malaysia has operated a very open trade regime since the 1960s and has pursued aggressive import substitution and export supporting policies. This development strategy is very different to that adopted in many other emerging economies where trade liberalisation has been associated with greater wage inequality. The aim of the present study is to examine whether Malaysia's more open approach to international trade has had a similar effect on wage inequality. The results suggest, in fact, that this is not the case.
\end{abstract}

Keyword: Wage inequality; Trade openness; Malaysia 